\title{
Sympozjum naukowe "Granice prawa do sakramentów. Między Kodeksem Prawa Kanonicznego z 1917 roku a Kodeksem z 1983 roku", Kraków, 16 listopada 2017 r.
}

\begin{abstract}
Symposium "The limits of the right to the sacraments. Between the Code of Canon Law of 1917 and the Code of 1983", Krakow, November 16 ${ }^{\text {th }}, 2017$

In 2017 to mark the 100th anniversary of the Pio-Benedictine Code of Canon Law of 1917 the Faculty of Canon Law at the Pontifical University of John Paul II in Krakow organized a conference entitled "Limits of the right to the sacraments". It was held in Krakow on the $16^{\text {th }}$ of November 2017. The speeches, delivered in two sessions, concerned criteria for allowing children to first Holy Communion, and psychological conditions for receiving the sacraments of Confirmation, Holy Orders, and Holy Matrimony, as well as requirements for receiving the sacrament of the Anointing of the Sick.
\end{abstract}

Keywords: canon law, sacrament, right to receive a sacrament

Słowa kluczowe: prawo kanoniczne, sakrament, warunki udzielania sakramentów

W tym roku obchodziliśmy rocznicę 100-lecia Pio-Benedyktyńskiego Kodeksu Prawa Kanonicznego. Z tej rocznicowej okazji Wydział Prawa Kanonicznego Uniwersytetu Papieskiego Jana Pawła II w Krakowie zorganizował konferencję pt. „Granice prawa do sakramentów”, dookreśloną podtytułem „Między Kodeksem Prawa Kanonicznego z 1917 roku a Kodeksem z 1983 roku”. Gospodarz spotkania ks. prof. dr hab. Tomasz Rozkrut, Dziekan Wydziału Prawa Kanonicznego Uniwersytetu Papieskiego Jana Pawła II w Krakowie, przywitał gości przybyłych nie tylko z kraju, w tym z czołowych ośrodków prawa kanonicznego w Polsce, ale także z zagranicy. Szczególne słowa powitania ks. prof. dr hab. Tomasz Rozkrut skierował do Jego Ekscelencji Arcybiskupa Krakowskiego Marka Jędraszewskiego, Wielkiego Kanclerza Uniwersytetu Jana Pawła II, pełniącego również funkcję Przewodniczącego Rady Naukowej Konferencji 
Episkopatu Polski. Dziekan Wydziału Prawa Kanonicznego Uniwersytetu Papieskiego Jana Pawła II wskazał, że opisywane sympozjum zamyka cały cykl krajowych konferencji o Kodeksie Prawa Kanonicznego z 1917 roku, a zamysłem jego organizatorów było nie tylko swoiste domknięcie rozważań dotyczących Kodeksu Pio-Benedyktyńskiego przez obrady nad tematami dotychczas mniej poruszanymi w trakcie rocznicowych konferencji, ale także otworzenie dyskusji na przyszłość, jako że zmieniająca się rzeczywistość wymaga ciągłego dostosowywania prawa kanonicznego będącego prawem żywej wspólnoty Ludu Bożego.

Uroczystego otworzenia Sympozjum dokonał Arcybiskup Krakowski Marek Jędraszewski. Metropolita Krakowski zwrócił uwagę uczestników konferencji na okoliczności ogłoszenia Kodeksu Prawa Kanonicznego z 1917 r. Wielki Kanclerz Uniwersytetu Papieskiego Jana Pawła II w Krakowie powiedział, że można patrzeć na Kodeks Pio-Benedyktyński w kategoriach próby zdefiniowania Kościoła i jego posłannictwa, w szczególności wobec zmian wywołanych II wojną światową, upadkiem systemu kongresu wiedeńskiego z 1815 r. oraz powstaniem państw narodowych. Arcybiskup podniósł, iż temat przewodni konferencji - granice prawa do sakramentów - które zawsze przecież muszą występować, wymaga interpretacji w świetle nauczania Kościoła, jego misji i samorozumienia, w szczególności przez pryzmat postanowień konstytucji soborowej Lumen Gentium.

Następnie krótkie słowo wprowadzające w obrady skierował do uczestników Sympozjum ks. prof. dr hab. Wojciech Misztal, Prorektor Uniwersytetu Papieskiego Jana Pawła II w Krakowie. W swym wystąpieniu wskazał na kontekst, w jakim potocznie najczęściej postrzegane są sakramenty, a którego elementami są liturgia, kościelna architektura czy uroczystości rodzinne, podkreślając, że sakramenty zarazem są i powinny być przedmiotem refleksji prawniczej.

Ksiądz prof. Rozkrut oddał głos ks. dr. hab. Szymonowi Drzyżdżykowi, prof. UP JPII, który poprowadził pierwszą sesję obrad. Po zaproszeniu referentów do stołu prezydialnego głos oddano pierwszemu z nich, ks. dr. hab. Piotrowi Rygule, prof. UKSW, który wygłosił referat pt. „Kryteria dopuszczania dzieci do pierwszej komunii świętej”. Referent przedstawił historyczne tło i ewolucję regulacji warunków, jakie musiały być spełnione, aby dziecko mogło przystąpić do Wieczerzy Pańskiej. Wskazał na funkcjonującą do XII wieku praktykę udzielania sakramentu Komunii Świętej wkrótce po udzieleniu chrztu oraz stopniowe wydłużanie czasu pomiędzy tymi sakramentami. Szczególną uwagę poświęcił unormowaniom IV Soboru Laterańskiego, wprowadzeniu wymogu animi discretionis oraz ewolucji wymaganego wieku do pierwszego pełnego uczestnictwa w Eucharystii.

W dalszej kolejności wystąpiła dr Aleksandra Brzemia-Bonarek z przedłożeniem zatytułowanym „Czy do przyjęcia sakramentu bierzmowania konieczne jest używanie rozumu?" Pani doktor przedstawiła wpływ dekretu Quam singulari Piusa X na wiek, w którym udzielano bierzmowania, oraz dyskusję konsultorów nad unormowaniami w tym zakresie w trakcie prac nad projektem Kodeksu Prawa Kanonicznego z 1917 r., zwłaszcza w zakresie wymogu używania rozumu. W wystąpieniu tym przedstawiła także szerszą perspektywę bierzmowania w kontekście rozległego zagadnienia, jakim jest różne rozkładanie akcentów indywidualnego i wspólnotowego charakteru sakramentu w Kościołach Zachodnim i Wschodnim. Referentka podała również szereg przykła- 
dów z unormowań zagranicznych, zwłaszcza anglosaskich, dotyczących dopuszczania osób z niepełnosprawnością intelektualną do sakramentu bierzmowania.

Jako ostatni referent w pierwszej sesji wystąpił ks. dr hab. Lucjan Świto, prof. UWM w Olsztynie, prezentując zagadnienie „Od amencji do borderline. Dopuszczenie do małżeństwa osób z zaburzeniami natury psychicznej?”. Referent wskazał na generalne prawo człowieka do zawarcia związku małżeńskiego oraz wyjątkowy charakter zakazów jego zawierania zawartych w prawie kanonicznym. Zwrócono uwagę uczestników Sympozjum na ewolucję pojmowania zaburzeń natury psychicznej, poczynając od traktowania ich głównie w kategoriach pojęciowych chorób psychicznych i posługiwania się terminologią z zakresu psychiatrii we wczesnym okresie obowiązywania Kodeksu Pio-Benedyktyńskiego. Szczególna uwaga została poświęcona przedstawieniu nowych rodzajów zakłóceń psychicznych, niestanowiących klasycznych przypadków chorób psychicznych, i ich kwalifikacji w kontekście wad konsensu małżeńskiego.

Po przeprowadzeniu dyskusji oraz krótkiej przerwie kawowej przewodniczący drugiej sesji ks. prof. dr hab. Józef Krukowski, Prezes Stowarzyszenia Kanonistów Polskich, zaprosił wszystkich uczestników Sympozjum do udziału w jej dalszych obradach w ramach drugiej sesji, oddając następnie głos pierwszemu z referentów w tej sesji - ks. dr. Janowi Słowińskiemu, który wygłosił referat „Kandydaci do święceń ze skłonnościami homoseksualnymi”. W swoim przedłożeniu referent wskazał na konieczność skrupulatnego badania kandydata do święceń pod względem zdatności do stanu duchownego, a w szczególności tzw. dojrzałości afektywnej, m.in. poprzez badania psychologiczne. Omówiono również spór wokół wpływu skłonności homoseksualnych na ważność przyjęcia święceń kapłańskich.

Zamykając cykl wystąpień, jako ostatni głos zabrał ks. dr hab. Ambroży Skorupa, prof. KUL, który wystąpił z referatem zatytułowanym „Sakrament namaszczenia chorych - dla jakich chorych?”. W swoim przedłożeniu zwrócił on uwagę na wyjątkowy charakter sakramentu namaszczenia chorych. Po zarysowaniu ogólnych warunków udzielania sakramentów referent przedstawił w tym kontekście szczegółowe warunki podmiotowe przyjęcia sakramentu namaszczenia chorych, ale także praktykę ich udzielania, również w ujęciu historycznym.

Po wygłoszeniu referatów drugiej sesji Sympozjum i przeprowadzeniu dyskusji, w ramach której referenci odpowiadali na pytania uczestników konferencji, Dziekan Wydziału Prawa Kanonicznego Uniwersytetu Papieskiego Jana Pawła II ks. prof. dr hab. Tomasz Rozkrut skierował do wszystkich obecnych krótkie słowa podsumowania, w których wskazał na konieczność merytorycznej dyskusji nad problemami poruszonymi w referatach przy niezmiennym szacunku dla każdego człowieka. Złożywszy podziękowania referentom, prowadzącym obie sesje oraz pozostałym uczestnikom Sympozjum, Ksiądz Profesor zamknął uroczyście obrady. 